\title{
Prevention and Treatment of White Spot Lesions During and After Treatment with Fixed Orthodontic Appliances: a Systematic Literature Review
}

\author{
Kristina Lopatiene $^{1}$, Marija Borisovaite ${ }^{1}$, Egle Lapenaite ${ }^{1}$ \\ ${ }^{1}$ Department of Orthodontics, Lithuanian University of Health Sciences, Kaunas, Lithuania.
}

\author{
Corresponding Author: \\ Marija Borisovaite \\ S. Žukausko 12-36, LT-49253, Kaunas \\ Lithuania \\ Phone: +37065050213 \\ E-mail: marija.borisovaite@gmail.com
}

\begin{abstract}
Objectives: The aim of the systematic literature review is to update the evidence for the prevention of white spot lesions, using materials containing fluoride and/or casein phosphopeptide-amorphous calcium phosphate during and after treatment with fixed orthodontic appliances.

Material and Methods: Information search for controlled studies on humans published between January 2008 and February 2016 was performed in PubMed, ScienceDirect, Embase, The Cochrane Library. Inclusion criteria were: the English language, study on humans, patients undergoing orthodontic treatment with fixed appliances, randomized or quasi-randomized controlled clinical studies fluoride-containing product or casein derivates used throughout the appliance therapy or straightaway after debonding.

Results: 326 articles were reviewed (Embase 141, PubMed 129, ScienceDirect 41, Cochrane 15). Twelve clinical studies fulfilled all inclusion criteria. Use of fluoridated toothpaste had a remineralizing effect on white spot lesions (WSLs) $(\mathrm{P}<0.05)$; fluoride varnish and casein supplements were effective in prevention and early treatment of WSLs $(\mathrm{P}<0.05)$.

Conclusions: Early detection of white spot lesions during orthodontic treatment would allow implementing preventive measures to control the demineralization process before lesions progress. The systemic review has showed that the usage of fluoride and casein supplements in ameliorating white spot lesions during and after fixed orthodontic treatment is significantly effective. However the use of casein phosphopeptide-amorphous calcium phosphate can be more beneficial than fluoride rinse in the reduction of demineralization spots.
\end{abstract}

Keywords: casein phosphopeptide-amorphous calcium phosphate nanocomplex; dental white spot; fluoride; orthodontic brackets; orthodontics.

Accepted for publication: 17 June 2016

To cite this article:

Lopatiene K, Borisovaite M, Lapenaite E.

Prevention and Treatment of White Spot Lesions During and After Treatment with Fixed Orthodontic Appliances: a Systematic Literature Review

J Oral Maxillofac Res 2016;7(2):e1

URL: http://www.ejomr.org/JOMR/archives/2016/2/e1/v7n2e1.pdf

doi: $10.5037 /$ jomr.2016.7201 


\section{INTRODUCTION}

Demineralization or white spot lesion (WSL) development in the enamel in association with orthodontic treatment with fixed appliances remains a well-known clinical problem for dental specialists [1]. Various methods how to prevent its formation are discussed in the literature, but still it is not determined which one is the most effective. WSLs can become visible around fixed appliances within one month of bracket placement, although the formation of regular caries usually takes at least 6 months (Figure 1) [2]. Individuals with malocclusion usually have difficulty in performing proper oral hygiene because of many retention sites. In addition, bonding attachments to teeth make conventional oral hygiene more difficult, and can prolong plaque accumulation on tooth surfaces $[\underline{3}, \underline{4}]$. WSLs mainly appear on buccal surfaces of the maxillary teeth in the following order: lateral incisors, canines, premolars, and central incisors $[\underline{5}, \underline{6}]$. According to the literature the prevalence of WSLs after orthodontic treatment is about $50 \%$ and its prevention is the purpose of every orthodontist [7-12].

Primary prevention of WSLs can be done adjacent to fixed appliances and secondary prevention (treatment) is done when the braces are removed. WSLs can be very difficult or sometimes even impossible to improve when fixed appliances are removed, and complete resolution of the lesions can rarely be achieved, it influences aesthetics and the patients' satisfaction with their smile [13]. Moreover, untreated WSLs can lead to the formation of dental caries and restorative treatment. Saliva can re-mineralize WSLs to some degree, although this process is faster during the first few months, and later it becomes slower [14]. Thus an early prevention of the WSLs is one of the goals of modern orthodontic treatment.
Natural remineralization through saliva involving mineral gain in the surface layer of WSLs has little improvement on the aesthetics and structural properties in the deeper lesions $[\underline{15}, \underline{16}]$. Therefore, it is necessary to apply remineralizing agents to repair the deeper parts of WSLs for better aesthetic results [17]. The use of various fluoride and casein phosphopeptide-amorphous calcium phosphate (CPPACP) derivatives, such as high-fluoride toothpaste, varnish, mouth rinse, gel or topical cream used for remineralization was reported in literature [18-23]. In his study Willmot [24] concluded that CPP-ACP was capable of absorbing through the enamel surface and could influence the carious process. CPP-ACP is a delivering system that allows freely available calcium and phosphate ions to attach to enamel and reform into calcium phosphate crystals. In the clinical studies it was found that various methods are used for prevention of WSLs, but discussion which is the most effective method of the prevention is still proceeding.

The aim of the systematic literature review is to update the evidence for the prevention of WSLs, using materials containing fluoride and/or casein phosphopeptide-amorphous calcium phosphate during and after treatment with fixed orthodontic appliances.

\section{MATERIAL AND METHODS Protocol and registration}

This systematic review was conducted following the PRISMA (Preferred Reporting Items for Systematic Reviews and Meta-analyses) statement [25].

\section{Focus question}

Evaluating the results of scientific researches hypothesis arises if it is possible to prevent

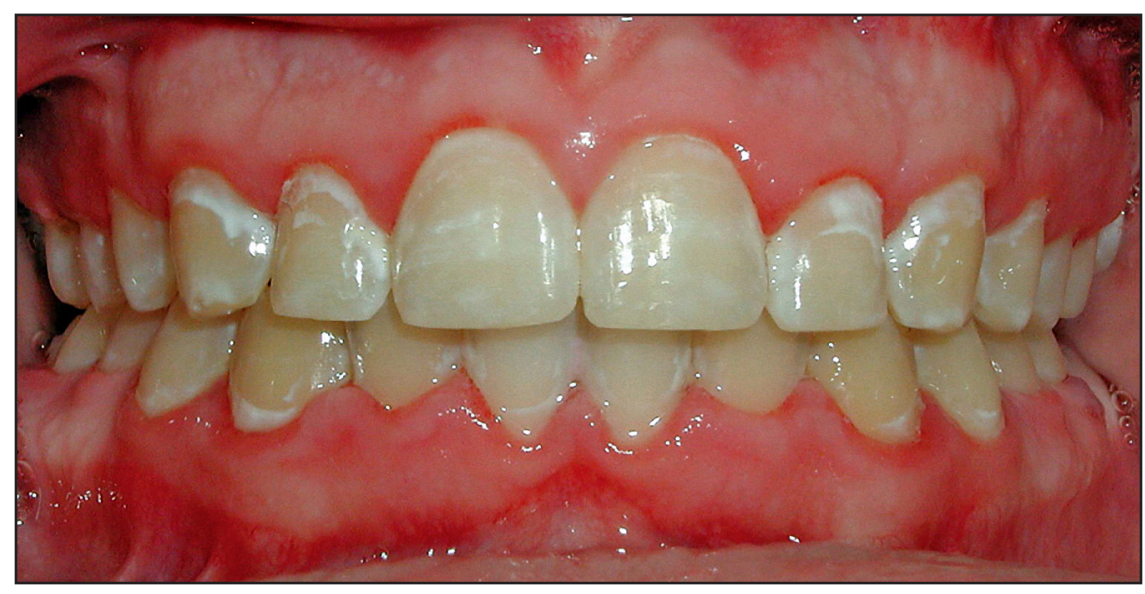

Figure 1. White spot lesions after orthodontic treatment with fixed appliances. 
development of WSLs using materials containing fluoride and/or casein phosphopeptide-amorphous calcium phosphate during and after treatment with fixed orthodontic appliances. The following focus question was developed according to the population, intervention, comparison, and outcome (PICOS) study design (Table 1).

\section{Types of publications}

The review included studies on humans published in the English language. Letters, editorials, literature reviews, $\mathrm{PhD}$ theses, and abstracts were excluded.

\section{Types of studies}

The review included all human prospective and retrospective follow-up studies and clinical trials, cohort studies, case-control studies, and case series studies published between January 2008 and February 2016, on development and prevention of WSLs, using materials containing fluoride and/or CPP-ACP during and after treatment with fixed orthodontic appliances.

\section{Information sources}

The search strategy incorporated examinations of electronic databases, supplemented by hand searches. The literature search was performed in PubMed (National Library of Medicine, NCBI), Embase, ScienceDirect and Cochrane databases. The references of each relevant study were screened to discover additional relevant publications and to improve the sensitivity of the search.

\section{Search}

The Pubmed, Embase, ScienceDirect and Cochrane databases were explored through advanced searches. The search was conducted using the following keywords: (casein phosphopeptide-amorphous calcium phosphate nanocomplex OR calcium phosphate OR casein phosphopeptide-amorphous OR CPP-ACP OR casein phosphopeptide amorphous calcium phosphate) AND (orthodontic brackets OR fixed appliances OR dental debonding OR bonding) AND (fluoride OR fluoride varnish OR fluoride rinse OR fluoride toothpaste) AND (orthodontics OR orthodontic treatment OR orthodontic treatment complications) AND (white spot lesion OR dental caries OR demineralization OR decalcification OR enamel defects).

The choice of keywords was intended to be broad, in order to collect as much relevant data as possible without relying on electronic means alone to refine the search results.

\section{Study selection}

The resulting articles were independently subjected to clear inclusion and exclusion criteria by two reviewers as follows. Reviewers compared decisions and resolved differences through discussion, consulting a third party when consensus could not be reached. The third party was an experienced senior reviewer.

\section{Inclusion and exclusion criteria}

Inclusion criteria for studies were:

- Study on humans;

- Patients of any age undergoing orthodontic treatment with fixed appliances;

- Preventive treatment of WSLs with fluoridecontaining product and/or casein derivatives.

Exclusion criteria for studies were:

- Non-human studies;

- In vitro studies;

- Subjects underwent any non-remineralizing therapy (bleaching or restoration) during trial.

Case reports and review studies were excluded.

Table 1. PICOS table

\begin{tabular}{c|l}
\hline Component & \multicolumn{1}{c}{ Description } \\
\hline Population & $\begin{array}{l}\text { Patients included in clinical studies that evaluate the effect of materials containing fluoride and/or casein phosphopeptide- } \\
\text { amorphous calcium phosphate on the WSLs during and after fixed orthodontic treatment. }\end{array}$ \\
\hline Intervention & $\begin{array}{l}\text { Use of materials containing fluoride and/or casein phosphopeptide-amorphous calcium phosphate on the WSLs on } \\
\text { patients with fixed appliances. }\end{array}$ \\
\hline Comparison & $\begin{array}{l}\text { Remineralization effect of materials containing fluoride and/or casein phosphopeptide-amorphous calcium phosphate } \\
\text { on the WSLs. }\end{array}$ \\
\hline Outcome & $\begin{array}{l}\text { Changes in the development of new WSLs and improvement of WSLs appearance while using materials containing } \\
\text { fluoride and/or casein phosphopeptide-amorphous calcium phosphate. }\end{array}$ \\
\hline Study design & Randomized and non-randomized controlled trials, cohort studies. \\
\hline
\end{tabular}




\section{Sequential search strategy}

Following the initial literature search, all article titles were screened to eliminate irrelevant publications, review articles, case reports, and animal studies. Next, studies were excluded based on data obtained from screening the abstracts. The final stage of screening involved reading the full texts to confirm each study's eligibility, based on the inclusion and exclusion criteria.

\section{Data extraction}

The data were independently extracted from studies in the form of variables, according to the aims and themes of the present review, as listed onwards.

\section{Data items}

Data were collected from the included articles and arranged in the following fields: participants, examination methods, preventive treatment methods, study design, main findings.

\section{Assessment of methodological quality}

The risk of bias assessment of the included trials was undertaken independently and in duplicate by at least two review authors as part of the data extraction process. This was conducted using the recommended approach for assessing risk of bias in studies included in Cochrane reviews [26].

\section{Synthesis of results}

Relevant data of interest on the previously stated variables were collected and organised into table.

\section{Statistical analysis}

No meta-analyses could be performed due to the heterogeneity between the studies.

\section{RESULTS \\ Study selection}

Article review and data extraction were performed according to the PRISMA flow diagram. The initial search identified a total of 326 references. Following the screening of the article titles, 135 potentially relevant articles were identified. Independent screening of the abstracts resulted in the selection of 42 publications for possible inclusion. The inclusion and exclusion criteria were applied to the 42 full-text articles. Finally, 12 articles that met the predefined criteria were included in the systematic review (Figure 2).

\section{Exclusion of studies}

The reasons for excluding studies after full-text assessment were as follows: non-human studies $(\mathrm{n}=1)$, in vitro studies $(\mathrm{n}=6)$, trials with patients who underwent any non-remineralizing therapy (bleaching or restoration) during trial $(\mathrm{n}=1)$, case reports and review studies $(n=9)$, could not be excluded before careful reading $(n=13)$.

\section{Quality assessment}

The quality assessment of the included studies revealed an unknown risk of bias (for one or more key domains) for the majority of the included studies $[\underline{5}, \underline{8}, \underline{19}, \underline{20}, \underline{27-34}]$, one study [르] was classified as low risk (of bias for all key domains) (Table 2).

Table 2. Bias summary

\begin{tabular}{l|c|c|c|c|c|c|c}
\hline & $\begin{array}{c}\text { Random } \\
\text { sequence } \\
\text { generation }\end{array}$ & $\begin{array}{c}\text { Allocation } \\
\text { concealment }\end{array}$ & $\begin{array}{c}\text { Blinding of } \\
\text { outcome } \\
\text { assessment }\end{array}$ & $\begin{array}{c}\text { Incomplete } \\
\text { outcome } \\
\text { data }\end{array}$ & $\begin{array}{c}\text { Selective } \\
\text { reporting }\end{array}$ & $\begin{array}{c}\text { Timing of } \\
\text { outcome } \\
\text { assessments }\end{array}$ & $\begin{array}{c}\text { Other } \\
\text { sources of } \\
\text { bias }\end{array}$ \\
\hline Baeshen et al. [5] & $?$ & $?$ & + & + & + & + & + \\
\hline Huang et al. [8] & $?$ & $?$ & + & + & + & + & + \\
\hline Enaia et al. [19] & $?$ & $?$ & $?$ & + & + & + & + \\
\hline Agarwal et al. [20] & $?$ & $?$ & + & + & + & + & + \\
\hline Akin et al. [27] & $?$ & $?$ & $?$ & + & + & + & + \\
\hline Du et al. [28] & $?$ & $?$ & $?$ & + & + & + & + \\
\hline Bailey et al. [29] & $?$ & + & + & + & + & + & + \\
\hline Richter et al. [30] & + & $?$ & $?$ & + & + & + & + \\
\hline Al Mulla et al. [31] & $?$ & $?$ & $?$ & + & + & + & + \\
\hline Robertson et al. [32] & $?$ & + & + & + & + & + & + \\
\hline Bröchner et al. [33] & + & + & $?$ & + & + & + & + \\
\hline Beerens et al. [34] & $?$ & + & + & + & + & + \\
\hline
\end{tabular}




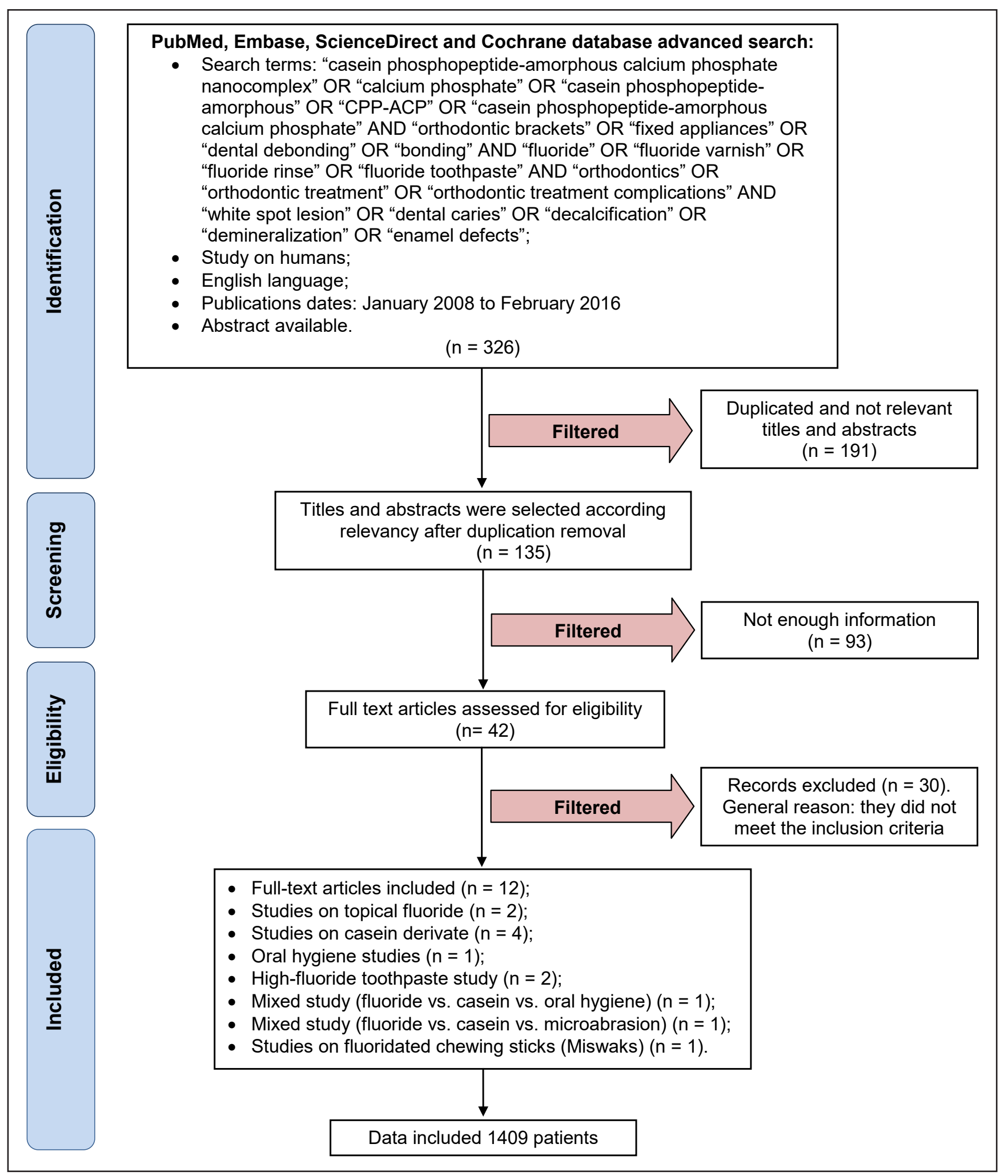

Figure 2. PRISMA flow diagram illustrating the literature search protocol.

\section{Study characteristics}

The included studies were compared regarding to the number of the participants, examination methods, preventive treatment methods, study design, main findings. The mentioned 12 articles were published between January 2008 and February 2016, two studies were performed exclusively on topical fluoride, two studies were performed on high-fluoride toothpaste, four studies were performed on casein derivate, there were one mixed study (fluoride vs. casein vs. oral hygiene) and one mixed study (fluoride vs. casein vs. microabrasion), also oral hygiene study and study performed on fluoridated chewing sticks (Miswaks). 


\section{Synthesis of results}

No meta-analysis could be performed due to the heterogeneity in the study designs and treatment modalities.

\section{Influence of materials containing fluoride and/or CPP-ACP on WSLS}

Multiple preventive agents had been tested over years to evaluate their effectiveness in prevention and treatment of WSLs associated with orthodontic treatment with fixed appliances. Materials containing fluoride and/or casein phosphopeptide-amorphous calcium phosphate have been proven to be the most effective in fighting demineralization [23].

Number of patients, examination methods, preventive treatment methods, study design, main findings (statistically significant) were used to determine which material is more effective in treatment and prevention of WSLs (Table 3).

Four clinical studies $[\underline{8}, 19, \underline{27}, \underline{30}]$ reported no better effect of products containing fluoride (fluoride varnish, fluoride toothpaste) on WSLs than normal home care for improving the appearance of WSLs. 4 of 12 studies showed significantly better results in WSLs appearance when using materials containing fluoride $[\underline{5}, \underline{20}, 28, \underline{31}]$. The use of CPP-ACP was reported to be more beneficial than fluoride rinse for postorthodontic remineralization [27]. Four clinical studies $[\underline{27}, \underline{29}, \underline{32}, \underline{33}]$ reported topical treatment with a CPP-ACP agent to significantly reduce are of WSLs and help in prevention of the development of WSLs. Two of 12 studies found no clinical advantage for use of the topical treatment with a CPP-ACP agent in improvement of the appearance of WSLs.

However, 9 of 12 studies proved treatment using materials containing fluoride and/or CPP-ACP to be beneficial for managing and preventing WSLs.

\section{DISCUSSION}

Prevention of demineralization during orthodontic treatment is one of the greatest challenges faced by clinicians despite modern advances in caries prevention. Evaluating short duration of time during which WSLs can develop and become irreversible, early diagnosis is considerably important, as modern dentistry is focused on a preventive approach instead of invasive restorations of carious defects. The individual oral hygiene status of orthodontic patients must be accurately followed especially in the first months of orthodontic treatment, in order to prevent
WSLs development and its complications [35]. The modern methods for the evaluation of WSLs are the following: the optical caries monitor, quantitative laser and light-induced fluorescence (QLF), digital imaging with fiber-optic transillumination, and computer analysis of digital photographs [4,27]. However, in most studies these techniques are not feasible because of budget limitations. The wellaccepted and most popular methods for WSLs evaluation are digital intraoral photography and QLF. Most relevant articles from the literature review used proportional rather than absolute measurements of luminance or size. Other studies used a combined scoring system based on the surface area and the severity of the opacity.

A number of scientific studies were performed over the last eight years in order to evaluate the effectiveness of the various remineralization methods, but data of these clinical researches were controversial. In some clinical studies, it was found that high-concentration fluoride varnish is significantly effective in reducing WSLs. Results of the experimental study, evaluating the effect of fluoride varnish, showed that high-concentration fluoride varnish reduces $40 \%$ of WSLs during orthodontic treatment [36]. Du et al. [28] in the randomized, parallel-group, controlled clinical trial stated that fluoride varnish was effective during the first three months after bonding and six months after debonding. In the other study the effectiveness of fluoridated chewing sticks in reducing WSLs in post-orthodontic patients was evaluated and its remineralization effect on WSLs was proved [5] Some scientist reported that the usage of highly fluoridated tooth paste and fluoride varnish during orthodontic treatment are significantly beneficial as a preventive material in the reducing WSLs around braces $[9,31,32,36]$. While Huang et al. [8] and Bailey et al. [29] discussed warnings against the use of high concentrations of fluoride because the superficial layer might prevent calcium and phosphate from penetrating to the deeper layers of the enamel, thus inhibiting deeper remineralization and limiting the cosmetic improvement of the WSLs. Richter et al. [30] concluded that fluoride varnish or fluoride mouth rinse was not effective, no significant association between the decrease in number of new lesions and application of materials containing fluoride was found. Contradictory results were reported in some clinical studies, no significant difference between the use of fluoride varnish, MI Paste or the usual oral hygiene using $1100 \mathrm{ppm}$ fluoride toothpaste, a toothbrush, and dental floss was found $[\underline{8}, \underline{30}]$. In these clinical trials size of the study sample, 
Table 3. Clinical studies evaluating the effectiveness of fluoride and casein supplements use in vivo

\begin{tabular}{|c|c|c|c|c|c|c|}
\hline Study & $\begin{array}{c}\text { Year of } \\
\text { publication }\end{array}$ & $\begin{array}{c}\text { Number of } \\
\text { patients }\end{array}$ & $\begin{array}{c}\text { Examination } \\
\text { methods }\end{array}$ & Treatment & Study design & Main findings \\
\hline $\begin{array}{l}\text { Baeshen } \\
\text { et al. [5] }\end{array}$ & 2011 & 37 & $\begin{array}{c}\text { DIAGNOdent } \\
\text { pen }\end{array}$ & $\begin{array}{l}\text { Fluoridated miswaks (impregnated in } \\
0.5 \% \text { sodium fluoride) } 5 \text { times per day } \\
\text { for } 6 \text { weeks after debonding. }\end{array}$ & $\begin{array}{c}\text { Double-blind, } \\
\text { randomized, } \\
\text { longitudinal trial }\end{array}$ & $\begin{array}{l}\text { Fluoridated miswaks had } \\
\text { a remineralizing effect on } \\
\text { WSLs }(\mathrm{P}<0.0001) .\end{array}$ \\
\hline $\begin{array}{l}\text { Huang } \\
\text { et al. [8] }\end{array}$ & 2013 & 115 & $\begin{array}{c}\text { Digital } \\
\text { photographs }\end{array}$ & $\begin{array}{l}3 \text { groups: } \\
\text { 1) an 8-week regimen of MI Paste } \\
\text { Plus; } \\
\text { 2) a single application of PreviDent } \\
\text { fluoride varnish; } \\
\text { 3) Control group - home care with } \\
1100 \text { ppm of fluoride toothpaste. }\end{array}$ & \begin{tabular}{|} 
Parallel-group \\
randomized trial
\end{tabular} & $\begin{array}{l}\text { MI Paste Plus and PreviDent } \\
\text { fluoride varnish do not } \\
\text { appear to be more effective } \\
\text { than normal home care for } \\
\text { improving the appearance of } \\
\text { WSLs over an 8-week period. }\end{array}$ \\
\hline $\begin{array}{c}\text { Enaia } \\
\text { et al. [19] }\end{array}$ & 2011 & 400 & $\begin{array}{c}\text { Digital } \\
\text { photographs }\end{array}$ & $\begin{array}{l}\text { Special cleaning instructions: } \\
\text { daily use of fluoride toothpaste, } \\
\text { fluoride mouth rinse, weekly use of } \\
\text { products with a high-fluoride content } \\
\text { (12.500 ppm of fluoride). }\end{array}$ & Cohort study & $\begin{array}{l}\text { New WSLs developed on } \\
60.9 \% \text { of the patients in this } \\
\text { survey despite the prevention } \\
\text { measures. }\end{array}$ \\
\hline $\begin{array}{l}\text { Agarwal } \\
\text { et al. [20] }\end{array}$ & 2013 & 31 & $\begin{array}{c}\text { Clinical } \\
\text { examination }\end{array}$ & $\begin{array}{l}2 \text { groups: } \\
\text { 1) fluoridated toothpaste three times a } \\
\text { week; } \\
\text { 2) nonfluoridated toothpaste. }\end{array}$ & $\begin{array}{c}\text { Double-blind, } \\
\text { randomized, } \\
\text { longitudinal trial }\end{array}$ & $\begin{array}{l}\text { There were statistically } \\
\text { significant differences } \\
\text { between the test group } \\
(\mathrm{P}<0.0001) \text {, but not in } \\
\text { the control group. Use of } \\
\text { fluoridated toothpaste had } \\
\text { a remineralizing effect on } \\
\text { WSLs. }\end{array}$ \\
\hline $\begin{array}{c}\text { Akin } \\
\text { et al. [27] }\end{array}$ & 2012 & 80 & $\begin{array}{c}\text { Clinical } \\
\text { examination; } \\
\text { digital } \\
\text { photographs }\end{array}$ & $\begin{array}{l}4 \text { groups: } \\
\text { 1) Control group; } \\
\text { 2) fluoride rinse, neutral } 0.025 \% \\
\text { sodium fluoride was used for } 30 \\
\text { seconds twice daily; } \\
\text { 3) CPP-ACP topical cream was applied } \\
\text { to the tooth surfaces twice a day; } \\
\text { 4) } 45 \text { microabrasion therapy sessions } \\
\text { were done at an interval of } 2 \text { weeks. } \\
\end{array}$ & $\begin{array}{c}\text { Parallel-group } \\
\text { randomized trial }\end{array}$ & $\begin{array}{l}\text { The use of CPP-ACP was } \\
\text { more beneficial than fluoride } \\
\text { rinse for postorthodontic } \\
\text { remineralization }(\mathrm{P}<0.05) \text {. } \\
\text { There was no significant } \\
\text { difference between the } \\
\text { success rates of treatment } \\
\text { with fluoride rinse and control } \\
\text { group. }\end{array}$ \\
\hline $\begin{array}{c}\text { Du et al. } \\
{[28]}\end{array}$ & 2012 & 96 & $\underset{\text { pen }}{\text { DIAGNOdent }}$ & $\begin{array}{l}\text { Fluoride varnish (5\% sodium } \\
\text { fluoride) or saline was applied onto } \\
\text { tooth surfaces with WSLs every } \\
\text { month during the first } 6 \text { months after } \\
\text { debonding. }\end{array}$ & $\begin{array}{l}\text { Randomized } \\
\text { controlled trial }\end{array}$ & $\begin{array}{l}\text { Topical fluoride varnish } \\
\text { application is effective } \\
\text { in reversing WSLs after } \\
\text { debonding. }\end{array}$ \\
\hline $\begin{array}{l}\text { Bailey et } \\
\text { al. [29] }\end{array}$ & 2009 & 45 & $\begin{array}{c}\text { Quantitative } \\
\text { light-induced } \\
\text { fluorescence; } \\
\text { digital } \\
\text { photographs. }\end{array}$ & Tooth Mousse/MI Paste. & $\begin{array}{l}\text { Randomized } \\
\text { controlled trial }\end{array}$ & $\begin{array}{l}\text { WSLs had a significantly } \\
\text { greater chance of regressing } \\
\text { at } 12 \text { weeks in the } \\
\text { remineralizing cream arm of } \\
\text { the study }(\mathrm{P}<0.05) \text {. }\end{array}$ \\
\hline $\begin{array}{l}\text { Richter et } \\
\text { al. [30] }\end{array}$ & 2011 & 350 & $\begin{array}{c}\text { Digital } \\
\text { photographs }\end{array}$ & $\begin{array}{l}4 \text { groups: } \\
\text { 1) oral hygiene instructions for all } 350 \\
\text { patients; } \\
\text { 2) topical fluoride applications for } 43 \\
\text { patients; } \\
\text { 3) fluoride rinse for } 42 \text { patients. }\end{array}$ & $\begin{array}{l}\text { Randomized } \\
\text { controlled trial }\end{array}$ & $\begin{array}{l}\text { A significant association was } \\
\text { with treatment duration } \\
(\mathrm{P}<0.01) \text { and the number of } \\
\text { oral hygiene discussions } \\
(\mathrm{P}<0.0001) \text {. } \\
\text { The preventive therapy was } \\
\text { not effective. }\end{array}$ \\
\hline $\begin{array}{l}\text { Al Mulla } \\
\text { et al. [31] }\end{array}$ & 2010 & 10 & \begin{tabular}{|c|} 
Clinical \\
examination; \\
radiographic \\
examination \\
(bitewings \\
taken with \\
double film) \\
\end{tabular} & $\begin{array}{l}\text { Colgate Max Cavity toothpaste (1450 } \\
\text { ppm of fluoride). }\end{array}$ & $\begin{array}{l}\text { Longitudinal, } \\
\text { randomized } \\
\text { clinical trial }\end{array}$ & $\begin{array}{l}\text { The use of Colgate } \\
\text { Max Cavity toothpaste } \\
\text { significantly reduces the } \\
\text { incidence of WSLs in } \\
\text { orthodontic patients } \\
(\mathrm{P}<0.001) .\end{array}$ \\
\hline $\begin{array}{l}\text { Robertson } \\
\text { et al. [32] }\end{array}$ & 2011 & 50 & $\begin{array}{c}\text { Digital } \\
\text { photographs }\end{array}$ & $\begin{array}{l}\text { MI Paste Plus using it each day at } \\
\text { night after brushing for } 3 \text { months. }\end{array}$ & $\begin{array}{l}\text { Prospective } \\
\text { randomized } \\
\text { controlled trial }\end{array}$ & $\begin{array}{l}\text { MI Paste Plus helped to } \\
\text { prevent the development } \\
\text { of WSLs and decreased the } \\
\text { number of WSLs already } \\
\text { present }(\mathrm{P}<0.05) \text {. }\end{array}$ \\
\hline $\begin{array}{l}\text { Bröchner } \\
\text { et al. [33] }\end{array}$ & 2011 & 50 & \begin{tabular}{|c|} 
Quantitative \\
light-induced \\
fluorescence; \\
digital \\
photographs \\
\end{tabular} & $\begin{array}{l}\text { Topical applications of Tooth Mousse } \\
\text { once daily for } 4 \text { weeks. }\end{array}$ & $\begin{array}{l}\text { Randomized } \\
\text { controlled trial }\end{array}$ & $\begin{array}{l}\text { Topical treatment with a } \\
\text { CPP-ACP agent significantly } \\
\text { reduced area of the lesions } \\
\text { after } 4 \text { weeks }(\mathrm{P}<0.05)\end{array}$ \\
\hline $\begin{array}{l}\text { Beerens } \\
\text { et al. [34] }\end{array}$ & 2010 & 54 & \begin{tabular}{|} 
Quantitative \\
light-induced \\
fluorescence
\end{tabular} & $\begin{array}{l}\text { MI Paste Plus used once a day at } \\
\text { bedtime. }\end{array}$ & $\begin{array}{l}\text { Double-blind } \\
\text { prospective } \\
\text { randomized } \\
\text { clinical trial }\end{array}$ & $\begin{array}{l}\text { No clinical advantage for use } \\
\text { of the MI Paste Plus over the } \\
12 \text { weeks was found. }\end{array}$ \\
\hline
\end{tabular}


duration of the fixed orthodontic treatment, period, when preventive remineralization procedures are used, are variable. The heterogeneous methodology was applied in order to evaluate the formation of WSLs. Therefore it influences the outcomes of the studies and clarifies the contradictory results of the effectiveness of the preventive procedures.

In recent scientific researches the use of MI Paste during orthodontic treatment was overlooked and its effect in remineralization of WSLs was confirmed $[29,32, \underline{33}]$. Although in some studies there was reported no significant usefulness of MI Paste or MI Paste Plus [8,34], some improvement in WSLs was found. Beerens et al. [34] compared the effectiveness of MI Paste on WSLs after orthodontic treatment with control group and stated that the size of the lesion area has not changed significantly over time or between the groups.

The other factor that can influence the reduction of WSLs is topical fluoride and CPP-ACP applications, which effectiveness was compared in several studies. For the last eight years clinical in vivo studies have been evaluating the effectiveness of fluoride and CPPACP therapy during and after orthodontic treatment with fixed appliances. The interest in secondary prevention of WSLs has increased noticeably. Some studies proved that high-fluoride derivates significantly reduces WSLs after 6 weeks to 6 months, while their opponent failed to demonstrate an additional effect of fluoride varnish compared with normal home care over an 8 week period $[5, \underline{8}, 28]$. The conclusions about the effect of CPP-ACP derivates are debatable, Bailey et al. [29] and Bröchner et al. [33] claimed that casein supplements are effective after 4 and 12 weeks, the opponents Huang et al. [ 8$]$ and Beerens et al. [34] proved in their trials that CPP-ACP is as effective as normal oral care over a 8 to 12 weeks period.

According to present study, the most important factors for preventing decalcification and formation of WSLs were a good oral hygiene regimen and a modifying diet with low carbohydrate intake $[\underline{3}, \underline{8}, \underline{30}, \underline{36}]$. Other additional methods such as fluoride varnish, rinse, chewing sticks, or CPP-ACP supplements did not totally prevent the formation of WSLs, but their incidence could be significantly reduced [37]. Clinical in vivo studies investigating WSLs prevention and treatment are still very rare. Some clinical studies were not comparable due to small sample sizes, various inclusion criteria, unreliable statistical analyses that failed to account for clustering effects and use of unproven assessment methods without relating them to more accepted techniques (only visual examination) $[\underline{20}, \underline{30}, \underline{33}, \underline{38}]$. The lack of high-quality clinical studies makes it difficult to determine whether various agents are effective and which of them are more effective than others. Concerns have been raised against the use of highly concentrated fluoride to assist remineralization since it may lead to unsightly staining. Though, there were no recent trials available that could either confirm or reject this important question. Evaluating the results of the present study, we can claim that the usage of fluoride and casein supplements during and after fixed orthodontic treatment is significantly effective in the reduction of demineralization spots, however the use of CPP-ACP can be more beneficial than fluoride rinse for postorthodontic remineralization. The need for new approaches and further highquality research has been emphasized $[\underline{1}, \underline{38}]$. It is also important to analyse if there are any other predictors for the degree of WSLs improvement - such as time since the removal of the appliances, or the severity of the lesions [8]. Further clinical studies evaluating the effectiveness of the methods for preventing and treatment of WSLs must be performed in order to get more clinically significant evidence of these measurements and standardized procedures have to be presented.

\section{CONCLUSIONS}

Early detection of white spot lesions during orthodontic treatment is of great importance as it would allow implementing preventive measures to control the demineralization process before lesions progress. The systemic review of studies performed over the last years has showed that the usage of fluoride and casein supplements in ameliorating white spot lesions during and after fixed orthodontic treatment is significantly effective in the reduction of demineralization spots. Clinical evidence showed that treatment using materials containing fluoride and/or casein phosphopeptide-amorphous calcium phosphate is beneficial for managing and preventing white spot lesions. For higher-risk patients additional measures such as high-concentrated fluoride varnish or casein derivate are recommended. The use of casein phosphopeptide-amorphous calcium phosphate can be more beneficial than fluoride rinse for postorthodontic remineralization. It is suggested to use casein phosphopeptide-amorphous calcium phosphate tooth mousse twice in addition to high fluoride toothpaste for 6 months to succeed in treating postorthodontic demineralized white spot lesions. Future clinical studies need to focus on the preventive measures in reducing the prevalence of white spot lesions. 


\section{ACKNOWLEDGMENTS AND DISCLOSURE STATEMENTS}

The authors declare that there are no financial or other conflicts of interest related to this publication.

\section{REFERENCES}

1. Bergstrand F, Twetman S. A review on prevention and treatment of post-orthodontic white spot lesions - evidence-based methods and emerging technologies. Open Dent J. 2011;5:158-62. [Medline: 21966335] [PMC free article: 3178902] [doi: $10.2174 / 1874210601105010158]$

2. Øgaard B. White spot lesions during orthodontic treatment: mechanisms and fluoride preventive aspects. Seminars in Orthod. 2008 Sep;14(3):183-93. [doi: 10.1053/j.sodo.2008.03.003]

3. Maxfield BJ, Hamdan AM, Tüfekçi E, Shroff B, Best AM, Lindauer SJ. Development of white spot lesions during orthodontic treatment: perceptions of patients, parents, orthodontists, and general dentists. Am J Orthod Dentofacial Orthop. 2012 Mar;141(3):337-44. [Medline: 22381494] [doi: 10.1016/j.ajodo.2011.08.024]

4. Lucchese A, Gherlone E. Prevalence of white-spot lesions before and during orthodontic treatment with fixed appliances. Eur J Orthod. 2013 Oct;35(5):664-8. [Medline: 23045306] [doi: 10.1093/ejo/cjs070]

5. Baeshen HA, Lingström P, Birkhed D. Effect of fluoridated chewing sticks (Miswaks) on white spot lesions in postorthodontic patients. Am J Orthod Dentofacial Orthop. 2011 Sep;140(3):291-7. [Medline: 21889073] [doi: 10.1016/j.ajodo.2010.04.034]

6. Chapman JA, Roberts WE, Eckert GJ, Kula KS, González-Cabezas C. Risk factors for incidence and severity of white spot lesions during treatment with fixed orthodontic appliances. Am J Orthod Dentofacial Orthop. 2010 Aug; 138(2): 188-94. [Medline: 20691360] [doi: 10.1016/j.ajodo.2008.10.019]

7. Al Maaitah EF, Adeyemi AA, Higham SM, Pender N, Harrison JE. Factors affecting demineralization during orthodontic treatment: a post-hoc analysis of RCT recruits. Am J Orthod Dentofacial Orthop. 2011 Feb;139(2):181-91. [Medline: 21300246] [doi: 10.1016/j.ajodo.2009.08.028]

8. Huang GJ, Roloff-Chiang B, Mills BE, Shalchi S, Spiekerman C, Korpak AM, Starrett JL, Greenlee GM, Drangsholt RJ, Matunas JC. Effectiveness of MI Paste Plus and PreviDent fluoride varnish for treatment of white spot lesions: a randomized controlled trial. Am J Orthod Dentofacial Orthop. 2013 Jan;143(1):31-41. [Medline: 23273358] [PMC free article: 4111089] [doi: 10.1016/j.ajodo.2012.09.007]

9. Beerens MW, Boekitwetan F, van der Veen MH, ten Cate JM. White spot lesions after orthodontic treatment assessed by clinical photographs and by quantitative light-induced fluorescence imaging; a retrospective study. Acta Odontol Scand. 2015 Aug;73(6):441-6. [Medline: 25423022] [doi: 10.3109/00016357.2014.980846]

10. Brown MD, Campbell PM, Schneiderman ED, Buschang PH.Apractice-based evaluation of the prevalence and predisposing etiology of white spot lesions. Angle Orthod. 2016 Mar;86(2):181-6. [Medline: 26241805] [doi: 10.2319/041515-249.1]

11. Pliska BT, Warner GA, Tantbirojn D, Larson BE. Treatment of white spot lesions with ACP paste and microabrasion. Angle Orthod. 2012 Sep;82(5):765-9. [Medline: 22352382] [doi: 10.2319/111611-710.1]

12. Yuan H, Li J, Chen L, Cheng L, Cannon RD, Mei L. Esthetic comparison of white-spot lesion treatment modalities using spectrometry and fluorescence. Angle Orthod. 2014 Mar;84(2):343-9. [Medline: 23984991] [doi: 10.2319/032113-232.1]

13. Karlinsey RL, Mackey AC, Stookey GK, Pfarrer AM. In vitro assessments of experimental NaF dentifrices containing a prospective calcium phosphate technology. Am J Dent. 2009 Jun;22(3):180-4. [Medline: 19650601]

14. Mayne RJ, Cochrane NJ, Cai F, Woods MG, Reynolds EC. In-vitro study of the effect of casein phosphopeptide amorphous calcium fluoride phosphate on iatrogenic damage to enamel during orthodontic adhesive removal. Am J Orthod Dentofacial Orthop. 2011 Jun;139(6):e543-51. [Medline: 21640866] [doi: 10.1016/j.ajodo.2010.09.027]

15. Cochrane NJ, Cai F, Huq NL, Burrow MF, Reynolds EC. New approaches to enhanced remineralization of tooth enamel. J Dent Res. 2010 Nov;89(11):1187-97. [Medline: 20739698] [doi: 10.1177/0022034510376046]

16. Yetkiner E, Wegehaupt F, Wiegand A, Attin R, Attin T. Colour improvement and stability of white spot lesions following infiltration, micro-abrasion, or fluoride treatments in vitro. Eur J Orthod. 2014 Oct;36(5):595-602. [Medline: 24385411] [doi: 10.1093/ejo/cjt095]

17. hen H, Liu X, Dai J, Jiang Z, Guo T, Ding Y. Effect of remineralizing agents on white spot lesions after orthodontic treatment: a systematic review. Am J Orthod Dentofacial Orthop. 2013 Mar;143(3):376-382.e3. [Medline: 23452972] [doi: 10.1016/j.ajodo.2012.10.013]

18. Guzmán-Armstrong S, Chalmers J, Warren JJ. Ask us. White spot lesions: prevention and treatment. Am J Orthod Dentofacial Orthop. 2010 Dec;138(6):690-6. [Medline: 21171493] [doi: 10.1016/j.ajodo.2010.07.007]

19. Enaia M, Bock N, Ruf S. White-spot lesions during multibracket appliance treatment: A challenge for clinical excellence. Am J Orthod Dentofacial Orthop. 2011 Jul;140(1):e17-24. [Medline: 21724067] [doi: 10.1016/j.ajodo.2010.12.016] 
20. Agarwal A, Pandey H, Pandey L, Choudhary G. Effect of fluoridated toothpaste on white spot lesions in postorthodontic patients. Int J Clin Pediatr Dent. 2013 May;6(2):85-8. [Medline: 25206198] [PMC free article: 4086591] [doi: 10.5005/jp-journals-10005-1195]

21. Srivastava K, Tikku T, Khanna R, Sachan K. Risk factors and management of white spot lesions in orthodontics. J Orthod Sci. 2013 Apr;2(2):43-9. [Medline: 24987641] [PMC free article: 4072374] [doi: 10.4103/2278-0203.115081]

22. Asaizumi M, Karlinsey RL, Mackey A, Kato T, Kuga T. In vitro assessments of white-spot lesions treated with NaF plus tricalcium phosphate (TCP) toothpastes using microtomography (micro-CT). J Dent Oral Hyg. 2013 Jul;5(7):68-76. [URL: http://www.academicjournals.org/journal/JDOH/article-abstract/4AEC3755437]

23. Montasser MA, El-Wassefy NA, Taha M. In vitro study of the potential protection of sound enamel against demineralization. Prog Orthod. 2015;16:12. [Medline: 26061985] [PMC free article: 4440871] [doi: 10.1186/s40510-015-0080-2]

24. Willmot D. White spot lesions after orthodontic treatment. Seminars in Orthod. 2008 Sep;14(3):209-19. [doi: 10.1053/j.sodo.2008.03.006]

25. Moher D, Liberati A, Tetzlaff J, Altman DG; PRISMA Group. Preferred reporting items for systematic reviews and metaanalyses: the PRISMA statement. Int J Surg. 2010;8(5):336-41. [Medline: 20171303] [doi: 10.1016/j.ijsu.2010.02.007]

26. Higgins JPT, Altman DG, Sterne JAC. Chapter 8: Assessing risk of bias in included studies. In: Higgins JPT, Green S, editors. Cochrane handbook for systematic reviews of interventions version 5.1.0. The Cochrane Collaboration. 2011. [URL: http://handbook.cochrane.org/index.htm\#chapter 8/8 assessing_risk of bias in included studies.htm]

27. Akin M, Basciftci FA. Can white spot lesions be treated effectively? Angle Orthod. 2012 Sep;82(5):770-5. [Medline: 22356705] [doi: 10.2319/090711.578.1]

28. Du M, Cheng N, Tai B, Jiang H, Li J, Bian Z. Randomized controlled trial on fluoride varnish application for treatment of white spot lesion after fixed orthodontic treatment. Clin Oral Investig. 2012 Apr;16(2):463-8. [Medline: 21331637] [doi: 10.1007/s00784-011-0520-4]

29. Bailey DL, Adams GG, Tsao CE, Hyslop A, Escobar K, Manton DJ, Reynolds EC, Morgan MV. Regression of post-orthodontic lesions by a remineralizing cream. J Dent Res. 2009 Dec;88(12):1148-53. [Medline: 19887683] [doi: 10.1177/0022034509347168]

30. Richter AE, Arruda AO, Peters MC, Sohn W. Incidence of caries lesions among patients treated with comprehensive orthodontics. Am J Orthod Dentofacial Orthop. 2011 May;139(5):657-64. [Medline: 21536209] [doi: 10.1016/j.ajodo.2009.06.037]

31. Al Mulla AH, Kharsa SA, Birkhed D. Modified fluoride toothpaste technique reduces caries in orthodontic patients: A longitudinal, randomized clinical trial. Am J Orthod Dentofacial Orthop. 2010 Sep;138(3):285-91. [Medline: 20816297] [doi: 10.1016/j.ajodo.2010.04.016]

32. Robertson MA, Kau CH, English JD, Lee RP, Powers J, Nguyen JT. MI Paste Plus to prevent demineralization in orthodontic patients: a prospective randomized controlled trial. Am J Orthod Dentofacial Orthop. 2011 Nov;140(5): 660-8. [Medline: 22051486] [doi: 10.1016/j.ajodo.2010.10.025]

33. Bröchner A, Christensen C, Kristensen B, Tranæus S, Karlsson L, Sonnesen L, Twetman S. Treatment of post-orthodontic white spot lesions with casein phosphopeptide-stabilised amorphous calcium phosphate. Clin Oral Investig. 2011 Jun;15(3):369-73. [Medline: 20383545] [doi: 10.1007/s00784-010-0401-2]

34. Beerens MW, van der Veen MH, van Beek H, ten Cate JM. Effects of casein phosphopeptide amorphous calcium fluoride phosphate paste on white spot lesions and dental plaque after orthodontic treatment: a 3-month follow-up. Eur J Oral Sci. 2010 Dec;118(6):610-7. [Medline: 21083623] [doi: 10.1111/j.1600-0722.2010.00780.x]

35. Bishara SE, Ostby AW. White spot lesions: formation, prevention and treatment. Seminars in Orthod. 2008 Sep;14(3): 174-82. [doi: 10.1053/j.sodo.2008.03.002]

36. Farhadian N, Miresmaeili A, Eslami B, Mehrabi S. Effect of fluoride varnish on enamel demineralization around brackets: an in-vivo study. Am J Orthod Dentofacial Orthop. 2008 Apr;133(4 Suppl):S95-8. [Medline: 18407027] [doi: 10.1016/j.ajodo.2006.09.050]

37. Behnan SM, Arruda AO, González-Cabezas C, Sohn W, Peters MC. In-vitro evaluation of various treatments to prevent demineralization next to orthodontic brackets. Am J Orthod Dentofacial Orthop. 2010 Dec;138(6):712.e1-7; discussion 712-3. [Medline: 21130326] [doi: 10.1016/j.ajodo.2010.05.014]

38. Benson PE, Parkin N, Millett DT, Dyer FE, Vine S, Shah A. Fluorides for the prevention of white spots on teeth during fixed brace treatment. Cochrane Database Syst Rev. 2004;(3):CD003809. Review. Update in: Cochrane Database Syst Rev. 2013;12:CD003809. [Medline: 15266503] 


\section{To cite this article:}

Lopatiene K, Borisovaite M, Lapenaite E.

Prevention and Treatment of White Spot Lesions During and After Treatment with Fixed Orthodontic Appliances: a Systematic Literature Review

J Oral Maxillofac Res 2016;7(2):e1

URL: http://www.ejomr.org/JOMR/archives/2016/2/e1/v7n2e1.pdf

doi: $10.5037 /$ jomr.2016.7201

Copyright (c) Lopatiene K, Borisovaite M, Lapenaite E. Published in the JOURNAL OF ORAL \& MAXILLOFACIAL RESEARCH (http://www.ejomr.org), 30 June 2016.

This is an open-access article, first published in the JOURNAL OF ORAL \& MAXILLOFACIAL RESEARCH, distributed under the terms of the Creative Commons Attribution-Noncommercial-No Derivative Works 3.0 Unported License, which permits unrestricted non-commercial use, distribution, and reproduction in any medium, provided the original work and is properly cited. The copyright, license information and link to the original publication on (http://www.ejomr.org) must be included. 